\title{
Differential Impacts of Climate on Tree Rings across a Topographic Gradient
}

\author{
Christopher L. Bouma ${ }^{1}$ and Marc D. Abrams ${ }^{1^{*}}$ \\ ${ }^{1}$ Department of Ecosystem Science and Management, Penn State University, 307 Forest Resources \\ Bldg., University Park, PA 16802, USA.
}

Authors' contributions

This work was carried out in collaboration between both authors. The author CLB designed the study, performed the statistical analysis, wrote the protocol and wrote the first draft of the manuscript. The author MDA also helped design the study and statistical analyzes, wrote and revised sections of the paper and contributed to literature review. Both authors read and approved the final manuscript.

Article Information

DOI: 10.9734/BJECC/2017/33378

Original Research Article

Received $12^{\text {th }}$ April 2017

Accepted $4^{\text {th }}$ May 2017

Published $3^{\text {rd }}$ July 2017

ABSTRACT

In 2012 and 2013 annual tree rings were measured in two co-occurring, yet contrasting tree species, the mesic red oak (Quercus rubra) and the more xeric chestnut oak (Quercus montana) across a topographic gradient to access differential impacts of climate and disturbance events. The study sites were located on the lower slope, southeast aspect, northwest aspect, and ridge top in the Ridge and Valley province of central Pennsylvania, USA. During the $20^{\text {th }}$ century, but prior to 1980, growth rates on most sites were statistically similar. After 1980, both species experienced significantly higher basal area increment (BAI) on southeast aspects than northwest sites. Increased growth rate was significantly correlated with increasing tree size. However, this relationship varied across site types and was impacted by disturbances from severe storms in the mid-1950s, 1966, and mid-1990s and gypsy moth outbreaks in the 1980s. Both species exhibited the highest frequency of tree ring releases on southeast aspects. Tree growth was also affected by temperature, precipitation and topographic position. Red oak growth was negatively correlated with current year temperature, particularly on northwest and ridge top sites. Chestnut oak growth responded positively to increasing temperature on southeast and lower slope sites. Moreover, red oak growth on northwest and ridge top locations were negatively correlated with winter temperatures while chestnut oak growth was positively correlated with winter temperatures on lower slope and southeast sites. We conclude that changing climate patterns, including increased temperature, precipitation, and extreme climatic events and site variability affected the growth rates of red oak and chestnut oak. 
Keywords: Dendrochronology; drought; temperature; disturbance; gypsy moth; ridge and valley; central Pennsylvania; United States.

\section{INTRODUCTION}

The impacts of global warming will be nearly ubiquitous in scale, as it can affect almost all ecosystem and physiological processes [1,2]. This includes biodiversity, nutrient and carbon cycling, sea level rise, fire frequency and intensity, drought, shifts in species ranges, tree mortality, and tree growth [3-9]. Many of these changes are considered to have negative impacts, but some positive effects do exist. One important example can be found in the eastern U.S. where some temperate trees are exhibiting a recent increase in growth relative to their historic average [10-12]. This increase is generally thought to be due to longer growing seasons and increases in temperature, precipitation, atmospheric $\mathrm{CO}_{2}$, and nitrogen $[13,14,15,16]$, but potentially modified by species, location, and site factors [17].

The average global temperature has risen by about $1.0^{\circ} \mathrm{C}$ in the last century, which mostly occurred in the last three decades $[2,18]$. This is attributed to a dramatic increase in anthropogenic-released greenhouse gases, mainly $\mathrm{CO}_{2}$ which has risen from $280 \mathrm{ppm}$ to 400 ppm [19,20,2,21]. Approximately 337 billion tons of carbon have been released into the atmosphere, most of which occurred between the mid-1970's and present-day [22]. As greenhouse gases continue on their current upward trend, temperatures are likely to follow [23]. Temperatures are projected to increase by 2 to $5^{\circ} \mathrm{C}$ over the next 100 years [2]. The Palmer Drought Severity Index (PDSI) indicates that very dry areas have more than doubled globally since the 1970s [24]. Additionally, intensity and frequency of major climatic events such as hurricanes are expected to increase [25]. Changes in ecosystem structure and function have, and will likely continue to be, impacted by these climatic variations $[26,11,27]$. However, the direction and magnitude of these changes will vary due to site variation $[17,28,29]$. The climate record for central Pennsylvania reveals four alternating periods during the last century (Fig. 1). It was relatively cool and dry from 1900 to 1930 and 1960 to 1970 and warm and wet from 1930 to 1960 and 1970 to 2010 . The last twenty years have contained the highest average annual temperature and total annual precipitation in the study period. Total annual precipitation increased by about $10 \mathrm{~cm}$ compared with the early $20^{\text {th }}$ century (Fig. 1). There was significant decrease in precipitation and PDSI through the early 1960s, which then increased to the present-day.

Several methods are available for evaluating changes in ecosystem processes. One such method is dendrochronology, the study of annual tree rings to determine the effects of climate on tree growth [30,31,32]. Three major climatic variables often used to evaluate tree growth are temperature, precipitation, and the Palmer Drought Severity Index (PDSI). The growth of mature trees has been positively correlated with recent changes in temperature throughout the northern hemisphere and across a broad spectrum of site conditions [33]. However, drought may override temperature causing a decrease in tree growth even in northern regions [34]. Nevertheless, diameter growth of northern tree species has generally increased due to warming $[35,36,11,12]$. Additionally, trees growing in high, cold limited environments have also seen a positive growth response to temperature [32,37]. Way and Oren [37] hypothesize that trees growing in cold temperature environments (e.g., northern and high elevation locations) will likely have increased growth rates due to global warming, whereas the opposite may be true for trees in warm or hot locations (e.g., tropics). Other factors such as moisture and drought also contribute to tree growth. Mäkinen et al. [38] reported that the growth of Norway spruce (Picea abies) growing at the northern extreme of its range was significantly correlated with temperature while southern specimens had a stronger correlation with moisture. Jump et al. [39] found significant growth declines in European beech (Fagus sylvatica) as temperature increased in its southern, drought limited range. The interacting effects of both increasing temperature and drought may lead to changing physiological function of trees growing in warm or cold regions $[40,41,34]$. Again, moisture can dominate temperature in relation to tree growth in warm or drought stressed areas. We hypothesize that temperate trees on wetter locations have experienced a greater response to increased temperature than those on drought limited locations. Varying influence of changing climatic patterns on a broad geographic scale may also be evident in local geographic variation. Very few studies have addressed topographic 
variation in tree ring growth to climate change $[17,42,28]$.

The concepts of broad spatial variation may be scaled down to a local level to evaluate how changing climate has the potential to impact tree growth based on geographic and species variability $[17,43]$. A study by Abrams et al. [17] indicated that northern red oak (Quercus rubra) exhibited a significant decrease in growth rate on xeric ridge sites due to drought not seen on mesic sites. White oak ( $Q$. alba) in xeric conditions grew more slowly than those in more mesic conditions in response to temperature, precipitation, and PDSI [44]. Fekedulegn et al. [28] reported that chestnut oak ( $Q$. montana) in West Virginia grew faster on southwest facing slopes than those facing northeast and showed little response to increasing drought conditions. In contrast, tulip poplar (Liriodendron tulipifera) and red maple (Acer rubrum) grew faster on northeast facing slopes while red oak did not show overall growth differences in response to aspect. While these studies provide a glimpse of information, much is still unknown.

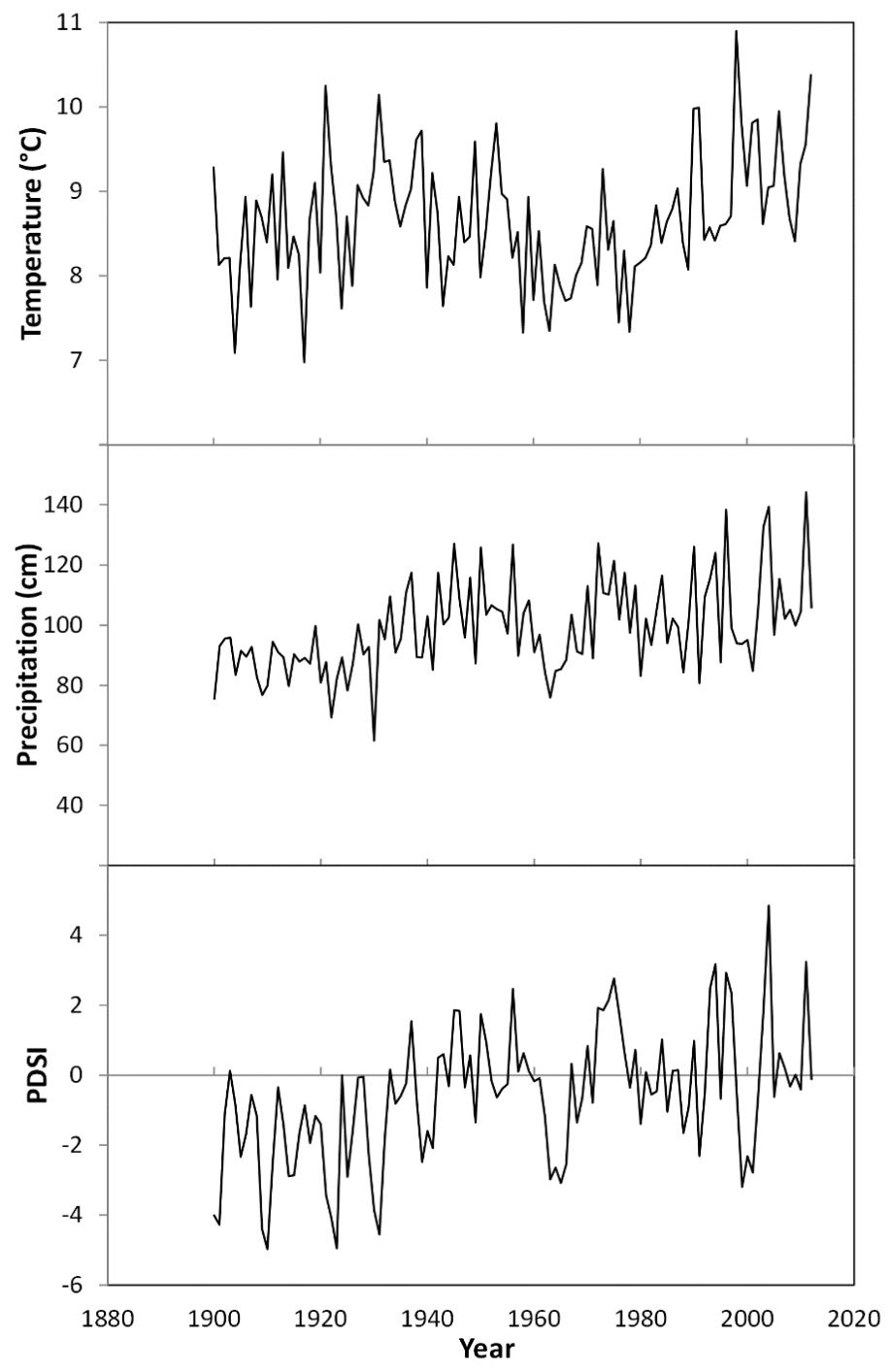

Fig. 1. Climatic data for central Pennsylvania (Region 7, NOAA) including average annual temperature, total annual precipitation, and average annual Palmer Drought Severity Index (PDSI) from 1900 to 2012.

Data from: ncdc.noaa.gov [115] 
In addition to climate and tree size, tree growth is also impacted by disturbance events. In general, disturbances cause increased growth of unaffected trees. Major disturbance types in Pennsylvania include insect outbreaks, ice storms, and hurricanes. Gypsy moth (Lymantria dispar L.) defoliation plays a significant role in growth of oak species. Defoliation decreases growth, potentially resulting in mortality, but subsequent recovery from damage is not unusual $[45,46]$. Trees not defoliated may experience release [47]. Similarly, ice storms or glaze events often cause damage to trees while neighboring trees receive a benefit in increased light and decreased competition [48]. Major hurricane events often result in more permanent individual tree damage resulting from blowdown or crown mortality [49]. This also augments growth by increasing light availability for remnant trees [50]. One effect of climate change is the projected increase in future hurricane frequency [25]. This escalation in severe climatic events may increase frequency of forest disturbance.

The objectives of this study are to evaluate growth responses of trees growing along an elevation gradient (from lower slopes to ridge tops) with respect to species type, topographic position, and regional climate in central Pennsylvania. This study will examine variations in tree ring growth rates among ecologically contrasting tree species (red oak and chestnut oak) within similar sites and between different sites and as a function of size.

\section{METHODS}

Four different site types along a topographic gradient were used for study; these are lower slope, mid-slope with a northwest aspect, midslope with a southeast aspect, and ridge top (Table 2). Three ridge locations were selected (Thickhead, Nittany, and Tussey) each containing one replicate per site type as determined by soil type, species composition, designated elevation, and aspect. The ridge tops average $671 \mathrm{~m}$ elevation. Mid-slope sites average $533 \mathrm{~m}$ in elevation on both southeast and northwest aspects of the ridges. Lower slopes, including stream valleys average $442 \mathrm{~m}$ elevation. One transect parallel to the ridge contour was placed at each site. Five variable radius plots 60 meters apart at each site using a 10 factor wedge prism were established at each site for forest composition sampling. All trees greater than $10 \mathrm{~cm}$ diameter at breast height were recorded and assigned to a dominant, co- dominant, intermediate, or overtopped canopy class. Prominent understory and shrub species were also recorded at each plot and estimated into cover classes of $0-5 \%, 5-25 \%, 25-50 \%, 50-$ $75 \%$, or $75-100 \%$. Red oak and chestnut oak tree cores were collected for radial growth analysis along the forest sampling transect during the summer of 2013. At least fifteen dominant and co-dominant trees were chosen to minimize growth variation and competition with the lower canopy strata. One increment core per tree was collected $0.3 \mathrm{~m}$ from the uphill base of the tree parallel to the ridge top to avoid reaction wood. The diameter at $0.3 \mathrm{~m}$ was also measured for each tree.

In the lab, the tree cores were glued to wooden mounting blocks, dried, and sanded with incrementally finer grained sand paper (60 grit, 100 grit, 320 grit, 400 grit, in some cases 600 and 1200 grit) to elucidate the rings. Crossdating of cores was performed using skeleton plotting and very narrow rings were identified to accurately attribute specific years to each tree ring [51]. The program Measure J2X (VoorTech Consulting, Holderness, NH, U.S.A.) and a "TA" UniSlide measurement system (Velmex, Inc., Bloomfield, NY) were used to measure and record annual rings to the nearest $0.001 \mathrm{~mm}$. The program COFECHA was used to validate cross-dating accuracy [52]. A few tree cores $(n<10)$ that we were not able to crossdate were dropped from analysis. ARSTAN was used to combine individual tree cores to create a master chronology of each site and species combination using a bi-weight robust mean. ARSTAN was also used to create a standardized ring width index (RWI) by fitting a negative exponential curve or linear function through the data to remove non-climatic and age trends from growth [53]. Ring width index calculates the relative difference between actual versus predicted growth and thus has the potential to mask longterm growth trends [54,12]. For this reason, raw ring widths were also transformed into basal area increments (BAI) using the equation $\mathrm{X}-(\mathrm{X}-1)$, where " $X$ " is the basal area and " $X-1$ " is the basal area of the previous year. Basal area increment shows long term growth trends masked by the standardized RWI. However, this long term growth trend is often indicative of growth aggradation in young stands. Basal area increment was therefore transformed into "relative BAl" by calculating a percent change for each year from the previous ten year average to the following ten year average for each year. Raw ring widths and BAl were used to compare 
overall growth among sites. Raw ring widths were also used to determine release. Ring width index, $\mathrm{BAI}$, and relative $\mathrm{BAl}$ were used to determine climate correlations and to compare effectiveness of each metric. The RWI and BAI were also checked for inter series correlation between similar sites.

Species, study location, and site type were evaluated for differences in growth rates. The averaged decadal BAl of each tree core was calculated for each decade (i.e. 1930-1939, 1940-1949, etc.) and grouped by site. Cores were compared among similar sites using a series of two-tailed ANOVA's (Analysis of Variance) within each species and decade. A series of ANOVA's was used to evaluate differences in growth among different site types within each species and decade. The decadal averages were calculated for each site's basal area increment chronology. Each species was then analyzed for differences between site types for each decade. Basal area increment was also evaluated as a function of increasing tree diameter. All corresponding annual BAl values and diameter values were compiled by species and topographic position and fitted with both a boundary line curve and a regression line. All statistical analyses were performed in the statistical package $R$ (v. 3.0.2).

Tree ring growth and climate (annual and monthly) correlations (Pearson's productmoment test if data was normally distributed and Spearman rank correlation if normality was violated) and principle component analysis were performed for each species and site. Monthly average precipitation, temperature, and Palmer Drought Severity Index (PDSI) for central Pennsylvania (State Code 36, Division 7) were obtained from the National Oceanic and Atmospheric Administration (NOAA) climate data online system from years 1929 to 2012 (Fig. 3). Annual average temperature and total precipitation were derived from monthly data and used for annual correlation. Response function and correlation analysis was performed using $\mathrm{RWI}$ and BAI chronologies with monthly climate data in the program DendroClim 2002 for years 1930-2012 [55]. The desired tree ring metric and monthly climatic variables were input into the program DendroClim 2002. The desired time period for analysis (1930-2012) and the range of months (previous year May through current year August) were delimited. A bootstrap method selects a sample to create a data matrix of the monthly climate variables and tree ring values.
These are standardized using the column mean and standard deviations of the predictors and tree rings. For the correlation function, Pearson correlation coefficients are computed between the matrices. The eigenvalues are also computed for each matrix. The response function vector is determined between the eigenvalues of the predictors and tree ring. These steps are reiterated 1000 times and the median of the correlation and response functions are calculated along with significance based on the 95\% Percentile Range method [55]. Additional climate analyses were performed by correlating transformed BAI and transformed annual climate variables.

\subsection{Site Descriptions}

The study sites are located in the Ridge and Valley province of central Pennsylvania in Centre and Huntington counties and include Nittany Mountain, Thickhead Mountain, and Tussey Mountain in the Rothrock State Forest (Fig. 2: $\left.40.7100^{\circ} \mathrm{N}, 77.8183^{\circ} \mathrm{W}\right)$. The topography is characterized by parallel ridges oriented in the northwest and southeast facing directions. The study sites are approximately 80-110 year old, even-aged stands established after the clear-cut era, largely dominated by Quercus montana and Q. rubra (chestnut oak and red oak, respectively) $[56,57]$. Disturbances are common for this region, most notably fire, gypsy moth outbreaks, hurricane events, and winter storms. Fire shaped the region's forests through the $19^{\text {th }}$ century after which the "Smokey Bear" campaign led to the extinguishing of this important natural event [58]. More recently, major outbreaks of gypsy moth occurred in 1972, 1981, 1985, and 1990 [59]. Additionally, several moderate and major hurricane events have also taken place within the study period.

Using the USGS Web Soil Survey, soil types were chosen to ensure reasonable homogeneity among the sampled locations. The stratigraphy at all ridge top sites, the Tussey northwest site, and both Thickhead mid-slope sites consisted of a conglomerate of sandstone with embedded shale as a minor component. In contrast, shale was a dominant parent material at Nittany midslope sites, the Tussey southeast site, and all three lower slopes sites (usgs.gov) [60]. Despite these differences, the sites are largely located on well drained sandstone derived soils, mainly of the Laidig and Hazleton soil series [61]. The region has a mixture of dry continental and humid maritime climates. Winter is typically dry 
with temperatures from -7 to $2^{\circ} \mathrm{C}$ (DecemberFebruary) while summer conditions are warm and humid with temperatures from 14 to $28^{\circ} \mathrm{C}$.

\section{RESULTS}

\subsection{Site Type, Species, and Size Related Tree Ring Growth}

Red oak RRW on lower slope sites was significantly higher than the ridge top site (Fig. 3; $P<0.001$ ). Chestnut oak BAl on southeast and northwest sites was similar, but lower slope sites were greater than that on ridge top sites. In terms of species differences, red oak average RRW displayed higher growth than chestnut oak across all but the lower slope sites while red oak average BAl displayed higher average growth than chestnut oak on southeast sites.

Across the three study locations red oak average BAl increased the most on lower slope and southeast facing sites between 1930 and 2009 $(95.2 \%$ and $138.7 \%$, respectively; Fig. 4$)$. This increase was significantly greater than that on ridge top and northwest sites. Red oak growth on lower slope and southeast sites were higher $(P<$
0.001) than ridge top and northwest sites after 1979. With regards to chestnut oak, growth of trees on lower slope sites was typically higher than that on the other three sites, but the differences were not as large as that for red oak. On average, red oak BAI was greater than that of chestnut oak across all site types. However, chestnut oak had a higher percent change $(179.6 \%)$ on southeast sites than red oak (138.7\%).

Basal area increment of both species exhibited a positive relationship with diameter on all topographic positions, indicating that tree size has a definite impact on annual diameter growth (Fig. 5). Increased growth with tree size in red oak and chestnut oak was most evident on lower slope and southeast sites (note range variation in $y$-axis). Red oak had its highest diameter and BAl combination on lower slope sites, whereas chestnut oak had its highest growth on southeast aspect sites. Red oak BAI on lower slope and southeast sites and chestnut oak BAl on southeast sites rose faster with increased diameter than chestnut oak on lower slope sites and both species on northwest and ridge top sites $(P=0.048)$.
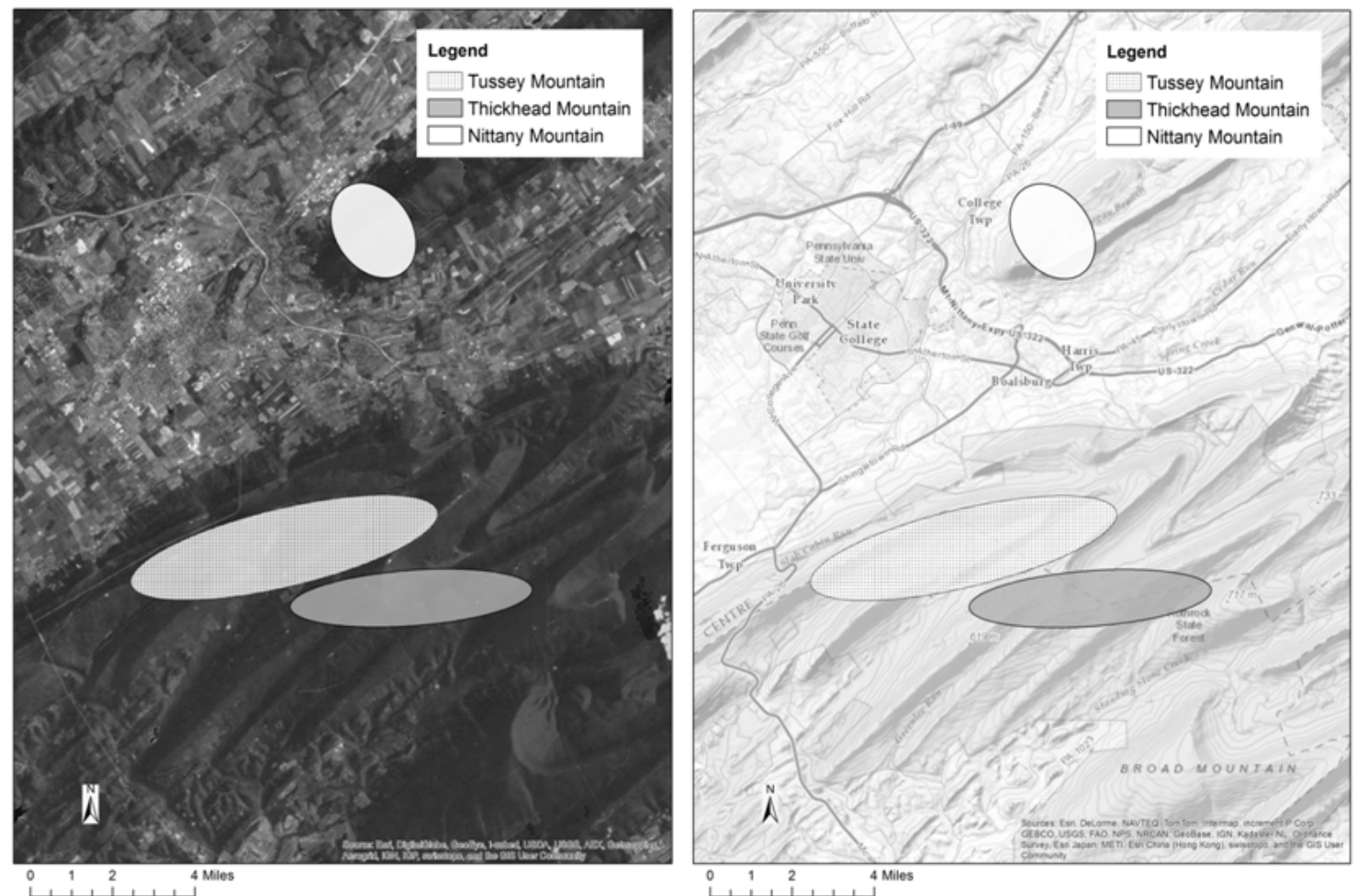

Fig. 2. Study site locations in centre and Huntington Counties of central Pennsylvania outlined on an aerial photograph (left) and topographic map (right) 


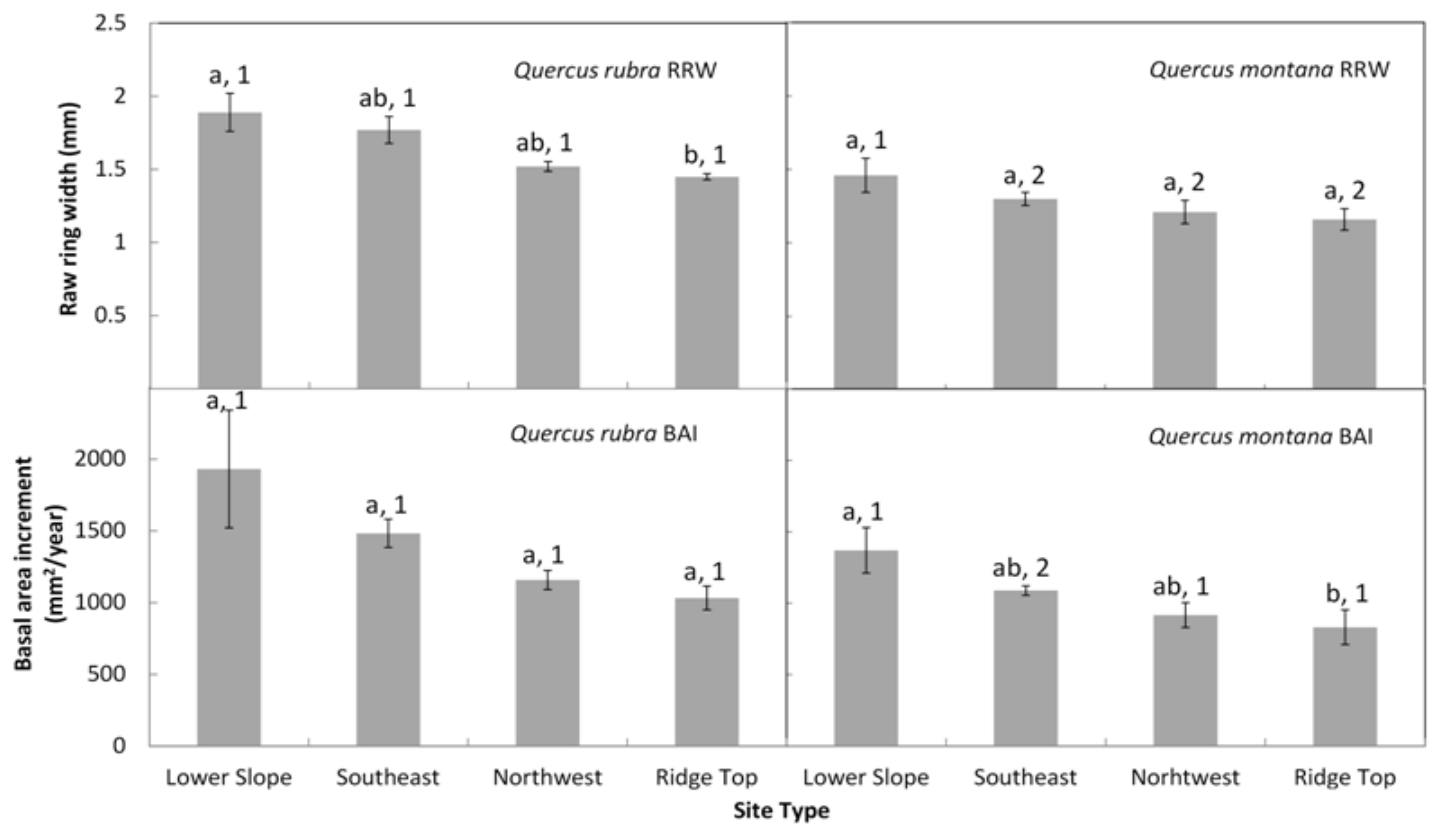

Fig. 3. Bar graph showing standard error around the averaged standard chronology (RRW) and basal area increment (BAl) of the three replicates within each site type for each species within the study period (1930-2012). Columns within a panel sharing a letter are not significantly different at $P<0.05$. Columns between different species panels of the same site type and metric sharing a number are not significantly different at $P<0.05$

\subsection{Climate Related Tree Ring Growth}

On northwest sites, red oak RWI was negatively correlated with current year temperature on Nittany and Tussey locations and previous year temperature on all three ridge locations (Table 2). Red oak RWI on Nittany and Tussey southeast sites displayed significant positive correlation with previous year precipitation. Chestnut oak RWI on southeast and northwest Thickhead and Tussey locations had significant positive correlation with previous year precipitation. Red oak displayed higher correlation with current and previous year temperature and precipitation on southeast versus northwest sites $(P=0.008$ and 0.031 , respectively). Red oak and chestnut oak RWI had higher correlation with previous year versus current year precipitation across all sites ( $P$ $=0.006$ and 0.002, respectively). The PDSI had a relatively positive effect, particularly on northwest and southeast sites.

Red oak RWI on the Thickhead lower slope site had significantly negative correlations with current year June and July temperatures while the Tussey location had the same relationship with current year February temperature (Fig. 6).
On all northwest sites, red oak RWI had significantly negative correlations with current year winter (January and February) and summer (June and July) temperatures. Red oak RWI on Nittany and Tussey northwest sites had significantly negative correlations with previous year summer temperatures. Red oak RWI on all southeast locations had significantly negative correlations with current year summer (June or July) temperatures. The Thickhead and Nittany southeast locations also showed significantly negative correlations with current year winter temperatures. On ridge top sites, red oak RWI had significantly negative correlations with current year winter temperatures at every location. In regard to chestnut oak, ring width index on lower slope sites had significantly positive correlations with previous year summer and winter temperature on the Nittany and Tussey locations. On northwest sites, chestnut oak RWI had significant positive correlations with previous year November temperature on the Nittany location and negative correlations with previous year September temperature on the Tussey location. On southeast sites, chestnut oak RWI on Nittany and Tussey locations displayed significant positive correlations with current year winter temperature. Chestnut oak 
RWI on the Thickhead ridge top site was significantly positively correlated with current year January temperature and negatively correlated with current year April temperature. Red oak and chestnut oak RWI had higher correlations with previous year summer and current year winter temperature on lower slope and southeast sites versus northwest and ridge top sites $(P<0.001$ and 0.04 , respectively). Chestnut oak had higher average correlations with monthly temperature than red oak across all sites $(P<0.001)$.

Red oak RWI on Thickhead and Tussey lower slope sites had significantly positive correlations with previous year fall and winter precipitation (Fig. 7). Additionally, red oak RWI on Thickhead and Nittany lower slope sites had significant positive correlations with current year summer precipitation. On northwest sites, red oak RWI on all locations had significant positive correlations with previous year summer months' precipitation. The same trend was evident on Thickhead and Tussey locations for current year summer months' precipitations. On southeast sites, red oak RWI had significant positive correlation with previous year December and current year summer month precipitations on Nittany and Tussey locations. Red oak RWI on Thickhead and Nittany ridge top sites had significant positive correlation with previous year summer precipitation. In regard to chestnut oak RWI, the Thickhead and Tussey lower slope locations had significant positive correlations with current year winter month precipitations. On northwest sites, chestnut oak RWI exhibited significant positive correlations with previous year summer month precipitations on all three locations and current

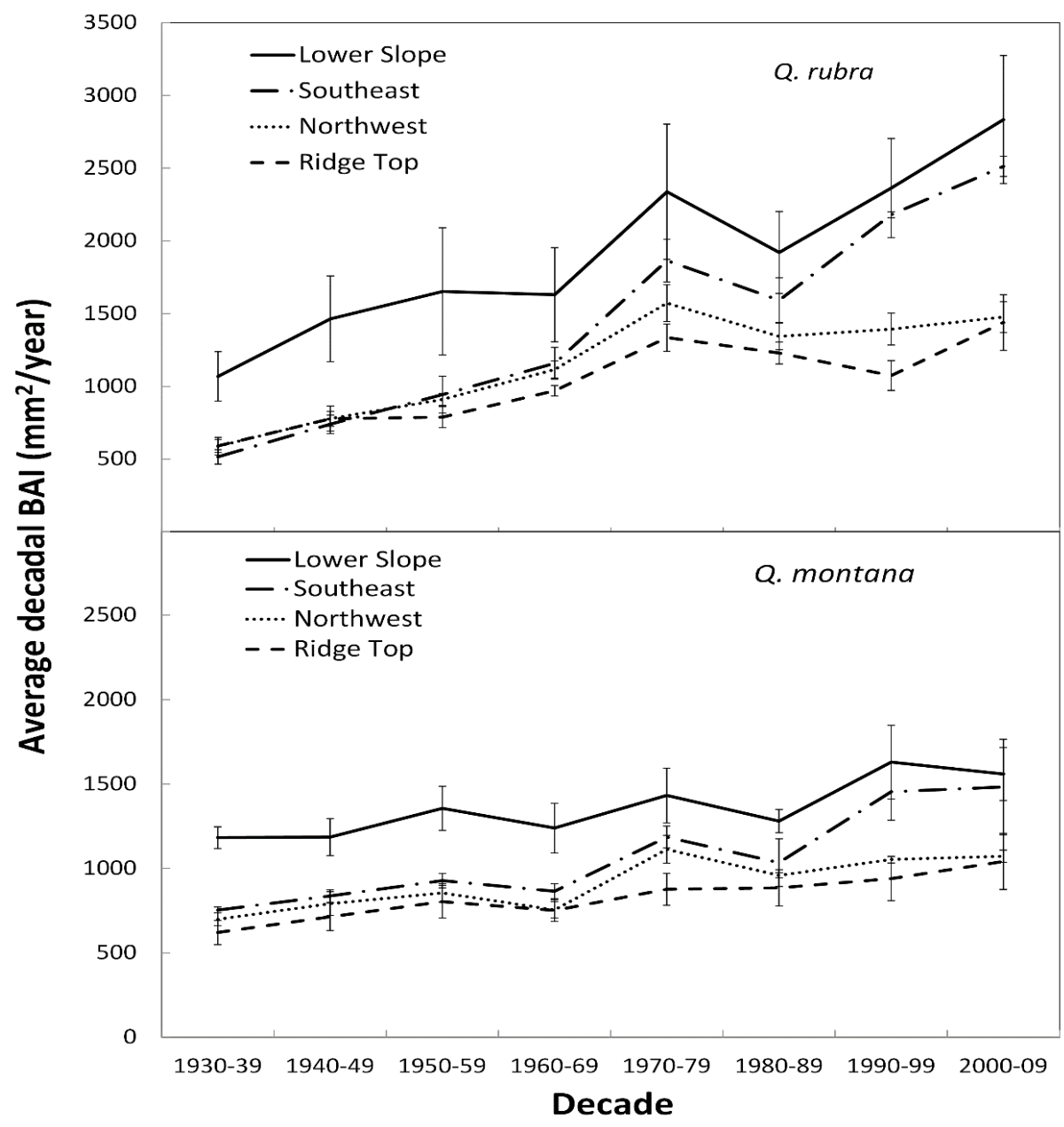

Fig. 4. Red and chestnut oak ten year basal area increment (BAl) chronologies averaged (士standard error) within site type across the three study locations from 1930-2009 
Table 1. Species relative importance values as determined by dominance and density for each study location and site type

\begin{tabular}{|c|c|c|c|c|c|c|c|c|c|c|c|c|}
\hline & \multicolumn{4}{|c|}{ Thickhead } & \multicolumn{4}{|c|}{ Nittany } & \multicolumn{4}{|c|}{$\begin{array}{c}\text { Tussey } \\
\end{array}$} \\
\hline & $\begin{array}{l}\text { Lower } \\
\text { slope }\end{array}$ & Southeast & Northwest & $\begin{array}{l}\text { Ridge } \\
\text { top }\end{array}$ & $\begin{array}{l}\text { Lower } \\
\text { slope }\end{array}$ & Southeast & Northwest & $\begin{array}{l}\text { Ridge } \\
\text { top }\end{array}$ & $\begin{array}{l}\text { Lower } \\
\text { slope }\end{array}$ & Southeast & Northwest & $\begin{array}{l}\text { Ridge } \\
\text { top }\end{array}$ \\
\hline Acer rubrum & 21.9 & 43.3 & 20.2 & 35.5 & 17.6 & - & 7.0 & - & 42.0 & 7.1 & 12.6 & 12.7 \\
\hline Betula lenta & 29.2 & 2.3 & 18.5 & 6.6 & - & 2.4 & 8.1 & - & 2.1 & 6.7 & 22.5 & 2.4 \\
\hline Nyssa sylvatica & 12.8 & 9.2 & 24.2 & - & - & - & - & - & 9.2 & 25.6 & 19.2 & 38.0 \\
\hline Quercus montana & 17.1 & 13.3 & 24.0 & 18.4 & 18.0 & 64.2 & 30.7 & 67.6 & 15.2 & 35.9 & 29.5 & 15.3 \\
\hline Quercus rubra & 11.0 & 23.9 & 13.2 & 16.8 & 36.3 & 23.0 & 47.9 & 21.2 & 7.1 & 16.5 & 16.2 & 23.3 \\
\hline Quercus alba & 1.4 & - & - & - & 2.1 & - & - & - & - & - & - & - \\
\hline Quercus coccinea & 6.7 & 1.6 & - & 22.7 & - & - & 1.1 & - & 3.9 & 8.2 & - & 6.4 \\
\hline Quercus velutina & - & 6.6 & - & - & 24.6 & 10.3 & 3.7 & 11.2 & 3.5 & - & - & - \\
\hline Tsuga canadensis & - & - & - & - & - & - & - & - & 1.6 & - & - & - \\
\hline Carya sp. & - & - & - & - & 1.4 & - & 1.5 & - & 10.7 & - & - & - \\
\hline Liriodendron tulipifera & - & - & - & - & - & - & - & - & 4.8 & - & - & - \\
\hline Pinus rigida & - & - & - & - & - & - & - & - & - & - & - & 2.0 \\
\hline
\end{tabular}

Table 2. Pearson product-moment correlation between current and previous year annual climate (average temperature $\left({ }^{\circ} \mathrm{C}\right.$ ), total precipitation $(\mathrm{cm})$, and average PDSI) and ring width index for northern red oak (NRO) and chestnut oak (CO) at each location site from 1930-2012 (df=81).

\begin{tabular}{|c|c|c|c|c|c|c|c|c|c|c|c|c|c|c|}
\hline & & & \multicolumn{3}{|c|}{ Lower slope } & \multicolumn{3}{|c|}{ Northwest } & \multicolumn{3}{|c|}{ Southeast } & \multicolumn{3}{|c|}{ Ridge top } \\
\hline & & & Thickhead & Nittany & Tussey & Thickhead & Nittany & Tussey & Thickhead & Nittany & Tussey & Thickhead & Nittany & Tussey \\
\hline \multirow{6}{*}{ 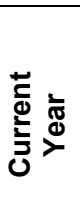 } & & Temperature & 0.098 & -0.088 & -0.037 & -0.164 & $-0.384^{* *}$ & $-0.330^{*}$ & -0.113 & -0.135 & -0.130 & -0.067 & -0.022 & -0.037 \\
\hline & NRO & Precipitation & 0.138 & 0.139 & 0.150 & 0.123 & -0.008 & 0.047 & 0.106 & 0.107 & $0.231^{*}$ & 0.029 & 0.023 & 0.017 \\
\hline & & PDSI & 0.154 & 0.202 & $0.282^{*}$ & $0.244^{*}$ & 0.200 & $0.261^{*}$ & $0.251^{*}$ & $0.295^{*}$ & $0.408^{\star *}$ & 0.131 & 0.141 & 0.063 \\
\hline & & Temperature & 0.026 & 0.098 & 0.058 & 0.101 & 0.016 & -0.002 & -0.006 & 0.038 & -0.010 & $0.219^{*}$ & 0.082 & $0.235^{\star}$ \\
\hline & $\mathrm{CO}$ & Precipitation & -0.007 & 0.067 & -0.050 & 0.150 & 0.058 & 0.170 & 0.137 & -0.001 & 0.172 & -0.082 & -0.104 & -0.034 \\
\hline & & PDSI & 0.060 & 0.116 & 0.082 & $0.236^{*}$ & 0.169 & $0.319^{* *}$ & $0.307^{* *}$ & 0.107 & $0.328^{* *}$ & -0.014 & -0.061 & -0.002 \\
\hline \multirow{6}{*}{ 号 } & & Temperature & 0.102 & -0.092 & 0.014 & $-0.264^{*}$ & $-0.400^{* *}$ & $-0.409^{* *}$ & $-0.236^{\star}$ & -0.198 & -0.185 & -0.207 & -0.088 & -0.086 \\
\hline & NRO & Precipitation & 0.202 & 0.101 & $0.248^{*}$ & 0.166 & 0.115 & 0.133 & 0.213 & $0.267^{*}$ & $0.229^{*}$ & 0.097 & $0.280^{* *}$ & 0.099 \\
\hline & & PDSI & 0.187 & 0.173 & $0.362^{*}$ & $0.300^{\star *}$ & $0.273^{*}$ & $0.341^{* *}$ & $0.349^{\star * *}$ & $0.388^{* *}$ & $0.457^{* *}$ & 0.142 & $0.364^{\star *}$ & 0.085 \\
\hline & & Temperature & 0.036 & 0.077 & 0.053 & -0.024 & 0.084 & -0.075 & -0.164 & 0.038 & -0.019 & 0.019 & 0.035 & 0.061 \\
\hline & $\mathrm{CO}$ & Precipitation & 0.168 & 0.081 & 0.201 & $0.285^{\star *}$ & 0.186 & $0.218^{*}$ & $0.307^{* *}$ & 0.192 & $0.233^{*}$ & 0.072 & 0.063 & 0.084 \\
\hline & & PDSI & 0.135 & 0.12 & $0.245^{\star}$ & $0.359^{* *}$ & 0.202 & $0.355^{\star *}$ & $0.437^{* *}$ & 0.201 & $0.371^{* *}$ & 0.16 & 0.075 & 0.124 \\
\hline
\end{tabular}




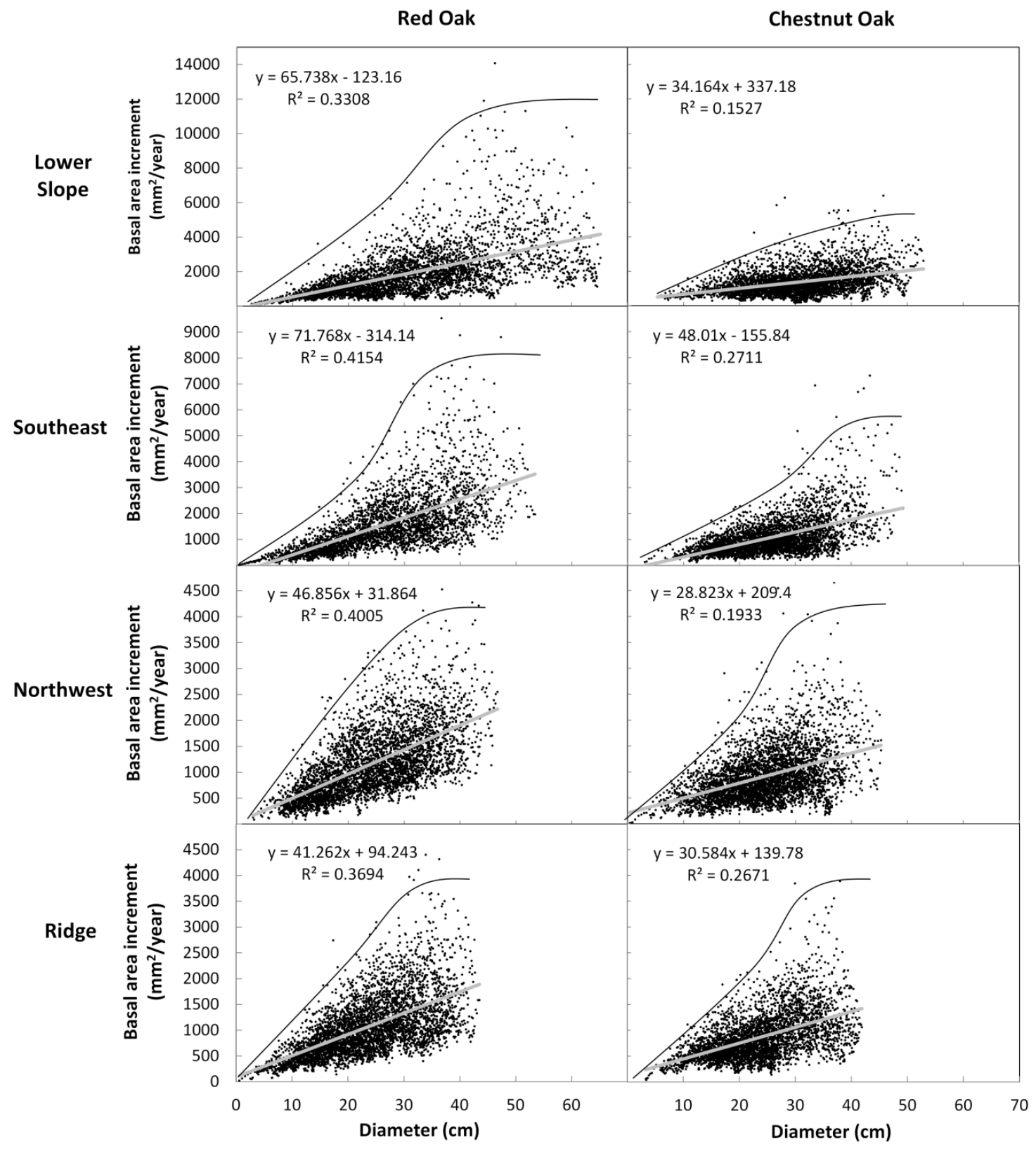

Fig. 5. Scatterplot and regression line relationship between diameter and basal area increment of red oak and chestnut oak on lower slope, southeast aspect, northwest aspect, and ridge top topographic positions. A boundary line curve was drawn encompassing the maximum (or near maximum) data values

year summer month precipitations on Thickhead and Tussey locations. On southeast sites, Thickhead and Tussey locations had significant positive correlations with current year winter month precipitations. Chestnut oak RWI on the Thickhead ridge top site had significant positive correlations with winter month precipitations while the Tussey ridge top site had the opposite trend. Red oak RWI had higher correlations with previous year August through January precipitation on lower slope and southeast sites versus northwest and ridge top sites $(P=0.002)$. 


\section{DISCUSSION}

This study investigated the impacts of species variation, tree size and age, site, climate, and disturbance on tree growth. All of these factors, either individually or in concert, were highly influential. The two study species were chosen because of their ecological and physiological contrasts. Chestnut oak is a predominantly xeric species and grows on ridge and barren sites in southern New England and throughout the Appalachian Mountains [62]. In contrast, northern red oak is a very widely distributed (from eastern
Canada to the southern Appalachians), generally mesic species that grows on good to high quality, lower elevation sites $[62,40,63]$. However, red oak in the Mid-Atlantic Ridge and Valley section can also grow on xeric sites [56,64]. An ecophysiological study reported that ecotypic variation in relation to moisture conditions and drought exists for red oak in central Pennsylvania [64]. Other studies have also reported that species growth and response to climate in the Appalachian Mountains varies by site type $[17,28]$.

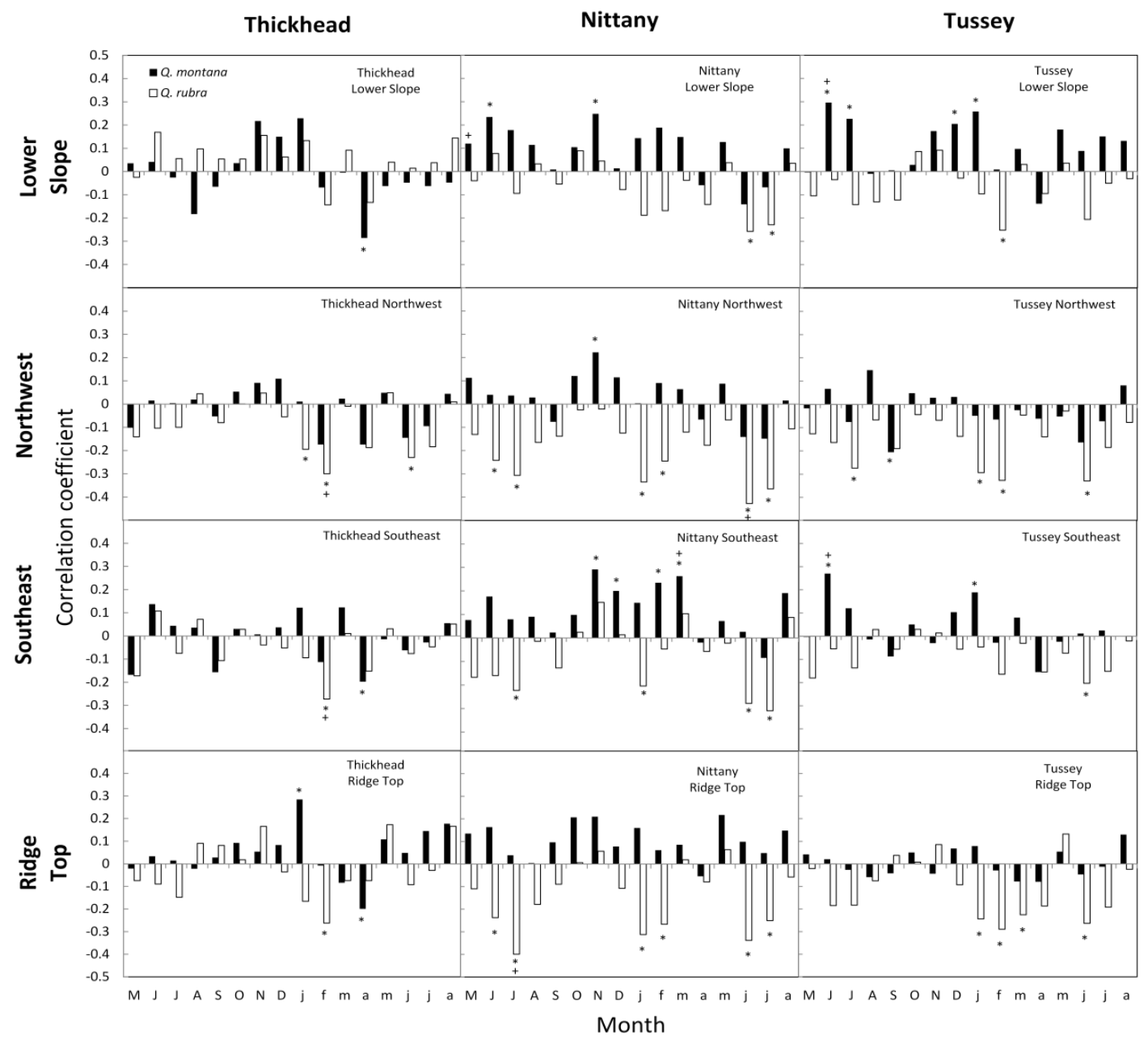

Fig. 6. Correlation coefficients between ring width index and monthly temperature of May of previous year to August of the current year (chestnut oak in black and northern red oak in white) derived from response function analysis. An * indicates a significant correlation value while a + indicates a significant response function 


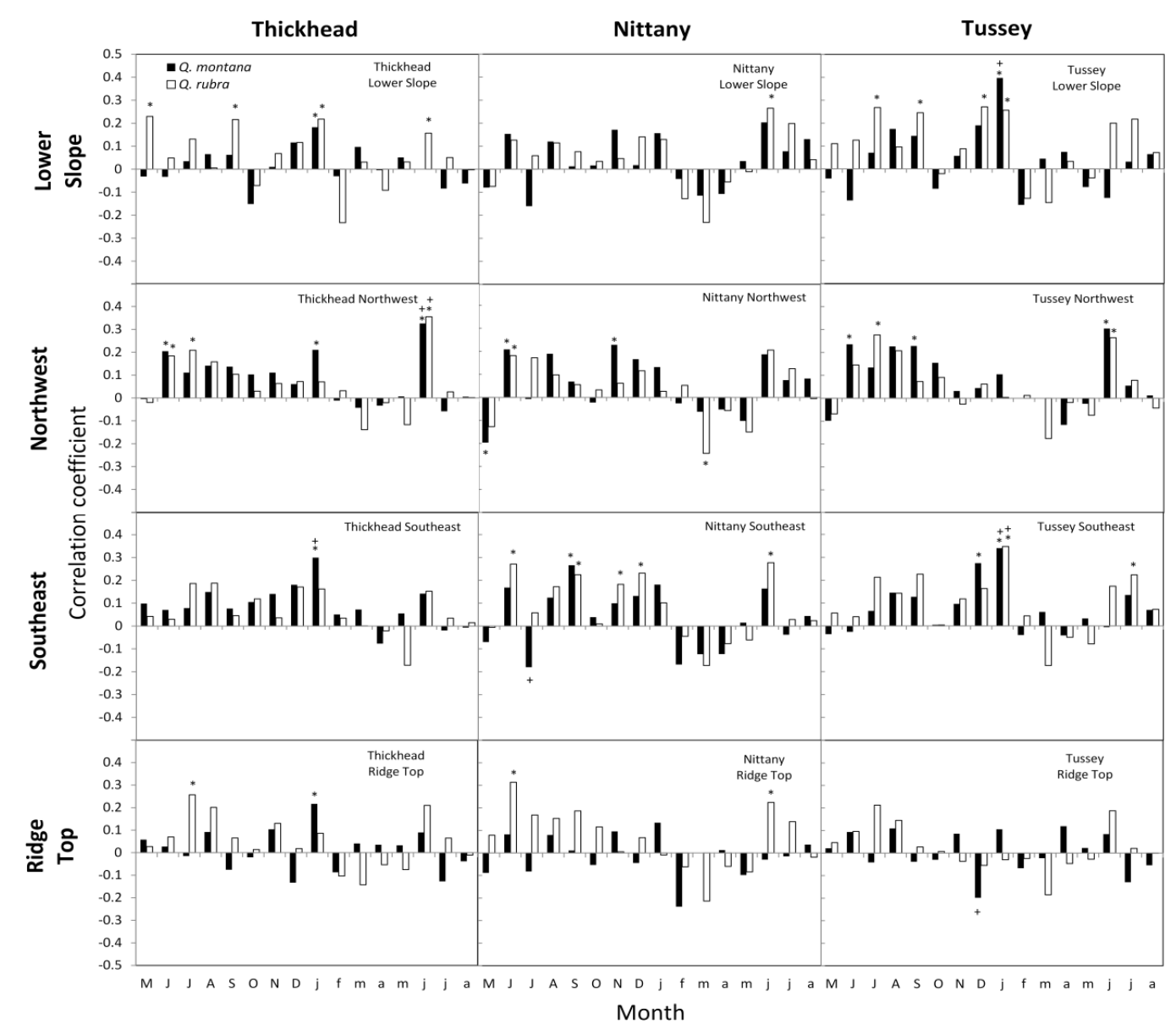

Fig. 7. Correlation coefficients between ring width index and monthly precipitation of May of previous year to August of the current year (chestnut oak in black and northern red oak in white) derived from response function analysis. An * indicates a significant correlation value while $\mathrm{a}+$ indicates a significant response function.

Growth differences between mesic and xeric adapted species arise from dissimilarities in ecophysiology, inherent growth capability, and ability to respond to external factors. Orwig and Abrams [65] reported that drought tolerant species had less reduction in growth rate two to six years following drought compared to mesic species. Xeric adapted species may even continue to exhibit increasing growth rates despite lack of water while mesic species may stay the same or decrease [66]. Kubiske and Abrams [67] found that xeric species maintained high photosynthetic rates during drought while mesic adapted species exhibited significant declines. This may be a function of lower shoot to root ratios, osmotic adjustment, and leaf and tissue adaptations in xeric species $[68,69,70,71]$. While xeric adapted trees may respond more positively to dry conditions than mesic species, they generally have inherently slower height or diameter growth rates when exposed to similar conditions. This is due in part to higher allocation to root growth and defensive growth strategies for survival during drought [72]. Like other dry adapted species, chestnut oak employs a slow growth strategy to survive on drier, more extreme conditions $[70,12]$. As a result, mesic oak species typically have faster growth rates than xeric oak species $[71,73]$. This was evident in our study as red oak had higher average BAl than chestnut oak across all site types. Fekedulegn et al. [28] also reported higher average red oak BAI versus chestnut oak across mesic and xeric sites. It has been postulated that mesic species require faster growth rates due to higher competition on better quality sites, whereas xeric species have slower growth as an adaptation or response to drier and more nutrient poor sites [73]. 
Growth rate is a function of tree age and size, whereby older and larger trees tend to have slower growth rates than their young counterparts [74]. Weiner and Thomas [75] suggest that trees exhibit a naturally occurring sigmoidal growth rate with increasing age similar to other organisms, largely as a function of size. This may be due to the effects of hydraulic limitations as trees increase in size and decreased photosynthesis in older trees $[76,77]$. Indeed, Mencuccini et al. [78] propose that age is important in determining growth in young trees but size-mediated controls assert dominance in older trees. Similarly, Niinemets [79] found a negative relationship existed between net assimilation rates per unit needle dry mass and tree height and age. Increased tree size also raises the competition with other trees for resources such as light and nutrients [80]. Decreased growth rate with age may also be associated with changing stand structure, although this may be reversed as a result of release events following small to moderate disturbance $[81,82]$.

In contrast to findings above, increasing growth rates have been reported in several tree species, including old-growth individuals in the eastern United States $[12,37,83]$. This may be due to global change phenomena, including elevated $\mathrm{CO}_{2}$ and temperature, increased precipitation and nitrogen deposition, disturbance and landuse changes. Indeed, both species in our study showed positive relationships between diameter and BAI through the study period. The boundary line drawn around diameter and BAI scatterplots demonstrated that red oak had the highest diameter and BAl combination on lower slope sites, whereas chestnut oak had its highest growth on southeast aspect sites. Moreover, red oak BAI on lower slope and southeast sites and chestnut oak BAI on southeast sites rose faster with increased diameter for chestnut oak on lower slope sites and both species on northwest and ridge top sites. This disparity in rate increase was uneven across topographic positions indicating a site influence.

Topographic position has a significant effect on air temperature, soil moisture, and soil nutrient composition, which may impact tree growth $[17,28]$. As discussed above, the temporal relationship between $\mathrm{BAl}$ and size of both species was greater on lower slopes and southeast sites. Red oak also had significantly higher average growth on southeast sites versus northwest and ridge top sites while chestnut oak experienced higher average growth on southeast versus ridge top sites, particularly after the 1970's. Middle and lower slope positions generally have higher moisture, lower $\mathrm{pH}$, and nutrient content than ridge tops $[84,85,86,87]$. Higher soil nutrient content, such as on mesic sites, may allow trees to allocate more energy to stem growth [88]. Furthermore, red oak BAI across the three locations had a higher percent increase than chestnut oak from 1930 to the end of the study period on all but the southeast aspect site, which had the highest percent BAI change through the study period $(179.7 \%)$. It is also interesting to note that the BAl of both species on northwest and southeast sites were similar in the beginning of the study period but statistically higher on southeast sites by the end of the study period. South facing aspects tend to be warmer and drier than their north facing counterparts $[89,28]$. While these less optimal conditions should lead to lower growth, the opposite trend is observed on this site type. This indicates that growth differences between northwest and southeast aspects may be a result of external factors besides inherent site characteristics. Fekedulegn et al. [28] found chestnut oak on southern aspects had a significant increase that they attributed to the development of a higher root to shoot ratio. Indeed, Addington et al. [90] found that longleaf pine (Pinus palustris Mill.) had $42 \%$ higher rootto-leaf area ratio on dry sites versus mesic sites.

Disturbances such as hurricanes and ice storms have historically shaped Pennsylvania's forest dynamics and can strongly influence tree growth in relation to site type [91,92]. Hurricane events can cause tree mortality or decreased growth due to blowdown and canopy damage [93]. However, remnant trees following a hurricane often benefit from increased light availability and decreased resource competition [50,94]. Gelber [95] suggested that winter storms most severely affect ridge top locations. This could explain the high frequency of release seen on ridge top sites during this period while still displaying an overall stagnated growth rate from higher postdisturbance rates over time. Additionally, gypsy moth outbreaks cause tree defoliation leading to growth declines. Ring widths on several sites were lower following gypsy moth outbreaks in 1981 and 1990 but recovery was rapid. Indeed, major insect damage causes growth declines in oak species but swift recovery often follows [46]. Growth increases may also be a result of release from drought following suppressed growth. An increase in growth following multiple drought 
years $(1963,1964$, and 1966) in conjunction with release from the major winter storm in 1966 potentially had aggregated effects promoting growth following this period.

Species growth responses to temperature differed among topographic positions and species. Chestnut oak generally had higher correlation with temperature than red oak. Abrams et al. [17] reported negative correlation between northern red oak tree ring growth and temperature, albeit on riparian sites. Red oak and chestnut oak on lower slope and southeast sites had higher temperature correlation relative to northwest and ridge top sites. Moreover, both species generally had higher correlation with temperature on southeast sites compared to similar northwest sites. Red oak BAl had significant negative correlation with summer temperatures on northwest and ridge top sites. Robertson [96] similarly found that oaks in southern Illinois were negatively correlated with current year June temperature. Previous studies suggest that this may be due to high evapotranspiration under increased temperatures [97]. Red oak BAls on northwest and ridge top locations were also negatively correlated with winter temperatures. Meanwhile, chestnut oak BAls on lower slope and southeast sites were positively correlated with winter temperatures. This complements findings of Pederson et al. [98] who also found oak species to be sensitive to January temperatures. This may be a result of lower damage from harsh overwinter temperatures [99]. In this study, chestnut oak BAI on two lower slope sites and one southeast site were significantly positively correlated with current year spring temperatures. Augspurger [100] suggested that cold spring temperatures may significantly shorten the growth season due to frost damage. Trees with more conservative growth strategies (such as chestnut oak) that have later leaf out dates despite early spring warming may be less affected by these events [101]. Warmer spring temperatures may promote earlier growth resulting in a longer growing season [99]. Hudson-Dunn and de Beurs [10] found that the start of the growing season on southern aspects could be as much as three weeks earlier than northern aspects due to higher temperatures and lower snow accumulation. This could partially explain higher growth and correlation with temperature on southeast aspects versus northwest sites. Fekedulegn et al. [28] indicated red oak growing on a southern aspect had a significant positive correlation with PDSI not seen on the north facing aspect. They attributed this to an adapted larger root to shoot ratio on drier southern aspects which facilitates positive growth rates despite temperature and moisture stress. Negative correlation between RWI and summer temperatures, even on southeast aspects, indicates that growth is more strongly linked to temperature prior to the start or at the beginning of the growing season than during current year growth. This suggests a potential indirect growth effect from temperature rather than a direct physiological response.

The precipitation of the current and previous years has a strong influence on tree growth by stimulating a wide range of physiological processes [103,104,105]. In this study, growth of both species across all topographic positions was positively influenced by increased previous year (August through September) precipitation. However, previous year summer through winter precipitation was more highly correlated with tree growth on lower slope and southeast versus northwest and ridge top sites. Additionally, late winter precipitation had significant correlation with growth on multiple lower slope and southeast sites. D'Arrigo et al. [105] similarly reported chestnut oak had high correlation with December and January precipitation in a New York forest. Black and Abrams [31] suggested high correlation with precipitation during winter months is a result of charging ground water for spring emergence. Fekedulegn et al. [28] found that red oak and red maple were positively correlated with precipitation on southern aspect slopes while those on northern aspect slopes were not. Saurer et al. [106] demonstrated that European beech (Fagus sylvatica) grown on dry sites had a more significant relation between stable carbon isotopes and precipitation than on wet sites, indicating higher water use efficiency. Overall more positive correlation with precipitation of both species on lower slope and southeast sites suggests increased precipitation and significant precipitation anomalies may elicit more enhanced growth than on northwest and ridge top sites.

Tree growth response to climate varies among sites, including those that are topographically or edaphically similar [1995]. Previous research indicates that aspect may be one such variable in determining tree ring response to climate [107]. Indeed, Peterson and Peterson [108] suggested that topographic aspect is important to consider when performing dendroclimatological studies. Other studies propose that sites sharing common 
features can be combined for climate analysis. However, such studies often underestimate tree growth variation on similar site types due to other site characteristics. Selecting only one representative sample for each site type of interest likely fails to capture underlying variation expressed in tree growth and climate response that is inherent among multiple sites. My study indicates that trees growing on different sites within the same site class (i.e., slope position) may not exhibit similar tree growth characteristics or climatic responses. Differences did not appear to be associated with variation in underlying parent material at similar aspects. However, other factors such as stand density may significantly affect tree growth response to climate. Gea-Izquierdo et al. [109] suggested that high and low density stands have similar climatic response trends but high density stands have a weaker signal. The Nittany locations had lower stand density compared to the other two locations. This may partially explain the more extreme climatic responses of the RWI to monthly temperatures observed across the Nittany mid-slope and ridge top sites.

Tree growth is affected individually by site, disturbance, tree size, and climate, but these may also work in concert for combined effects or interactions. Higher observed tree ring correlation with climate and high growth rates on lower slope sites may be due to higher resource availability [110,111]. However, higher climate correlation of both species on mid-slope southeast aspect sites versus northwest aspect sites is less intuitive. The answer may lie in an interaction between release and climate response. While disturbance can directly cause growth releases, it can also elicit increased climate response [112,113]. Indeed, McMahon et al. [16] found that increasing temperature positively influenced tree growth more than disturbance alone. Slopes oriented in south, southeast, or east directions are "exposed" while west, northwest, and north aspects are "intermediately exposed" [114,93]. Exposed sites experience more damage from hurricane events and may see more remnant tree release. Sheltered and lower slope sites are less susceptible to blowdown from high intensity winds compared to exposed slopes and ridge tops [93]. On the southeast sites, both species demonstrated higher correlation with temperature compared to northwest sites, potentially contributing to the higher observed growth than on northwest sites. Higher release frequency and intensity of red oak and chestnut oak on southeast aspect sites may facilitate the observed more positive climate response compared to northwest aspect sites. Despite these possible interactions, many conditions changing simultaneously make it difficult to isolate the effects of one factor.

\section{CONCLUSION}

Changing global climate patterns have and will continue to impact a wide range of biological processes. Tree growth in the Ridge and Valley province of central Pennsylvania has responded differently to several variables through the $20^{\text {th }}$ and into the $21^{\text {st }}$ century. Notably, trees at similar elevations but opposite aspects displayed distinct and different growth trends. We believe this is a result of tree adaptation to site characteristics and susceptibility to disturbance and changing climate. The more conservative chestnut oak generally responded more positively to temperature than did northern red oak. Tree growth was also indirectly affected by seasonal temperature and precipitation. While these factors promoted growth individually, it seems likely that tree growth response to climate was also stimulated by higher disturbance rates on specific site types. Despite similar trends, some distinctions in temperature response among similar sites indicate factors besides topographic position contribute to tree growth and climate interactions.

The unique approach used in this study of including a range of topographic sites and dendrochronological measures and responses to exogenous factors provided a more complete understanding of tree ring dynamics. The approach highlights the importance of capturing regional variability across replicated sites. Any one tree ring metric may provide a pattern of climate response but utilizing several metrics affords a more complete understanding. Indeed, utilizing multiple tree ring metrics provides complementary information that may be necessary for a stronger interpretation of climate, disturbance, and site effects on forests. Tree ring and climate correlations, disturbance, and size factors all contribute to variability in tree growth. However, because these have been examined individually, the relative impact of each factor is not fully understood. In the future, similar studies should endeavor to utilize a multivariate time series model that integrates tree size, climate relationships, and site characteristics to further elucidate changing tree growth patterns across a topographic gradient. 
The results of this study elucidate diverse tree growth patterns across the landscape resulting from changing climatic conditions. These findings suggest that as future climatic patterns continue to change, tree growth and survival will be affected depending on topographic position and species. Negative correlation between some tree species and site combinations with temperature may have detrimental impacts, leading to decreased survival if temperature continues to increase. This may be counteracted by high resource availability or disturbance related release. Moreover, trees that are less adapted to stressful conditions, such as red oak, may suffer these effects more severely. This could potentially lead to shifting forest composition due to climate warming and changes in the frequency and intensity of storm events.

\section{COMPETING INTERESTS}

Authors have declared that no competing interests exist.

\section{REFERENCES}

1. Karnosky DF. Impacts of elevated atmospheric $\mathrm{CO}_{2}$ on forest trees and forest ecosystems: Knowledge gaps. Environment International. 2003;29:161-169.

2. IPCC (Intergovernmental Panel on Climate Change). Climate Change 2007: Synthesis Report. Contribution of Working Groups I, II and III to the Fourth Assessment Report of the Intergovernmental Panel on Climate Change. Eds. R.K. Pachauri and A. Reisinger. IPCC, Geneva; 2007.

3. Keeling CD, Chin JFS, Whorf TP. Increased activity of northern vegetation inferred from atmospheric $\mathrm{CO} 2$ measurements. Nature. 1996;382:146-149.

4. Iverson LR, Prasad AM. Predicting abundance of 80 tree species following climate change in the eastern United States. Ecological Monographs. 1998;68: 465-485.

5. Beckage B, Osborne B, Gavin DG, Pucko C, Siccama T, Perkins T. Arapid upward shift of a forest ecotone during 40 years of warming in the Green Mountains of Vermont. Proceedings of the National Academy of Sciences. 2008;105:41974202.

6. Nemani RR, Keeling $C D$, Hashimoto $H$, Jolly WM, Piper SC, Tucker CJ, Myneni RB, Running SW. Climate-driven increases in global terrestrial net primary production from 1982 to 1999. Science. 2003;15601563.

7. Sheffield J, Wood EF. Projected changes in drought occurrence under future global warming from multi-model, multi-scenario, IPCC AR4 simulations. Climate Dynamics. 2008;31:79-105.

8. Van Mantgem PJ, Stephenson NL, Byrne JC, Daniels LD, Franklin JF, Fulé PZ, Harmon ME, Larson AJ, Smith JM, Taylor $\mathrm{AH}$, Veblen TT. Widespread increase of tree mortality rates in the western United States. Science. 2009;323:521-524.

9. Allen $C D$, Macalady AK, Chenchouni $H$, Bachelet D, McDowell N, Vennetier $M$, Kitzberger T, Rigling A, Breshears DD, Hogg EH, Gonzalez P, Fensham R, Zhang Z, Castro J, Demidova N, Lim J, Allard G, Running SW, Semerci A, Cobb N. A global overview of drought and heat-induced tree mortality reveals emerging climate change risks for forests. Forest Ecology and Management. 2010;259:660-684.

10. Abrams MD, Orwig DA. Structure, radial growth dynamics and recent climatic variations of a 320 year-old Pinus rigida rock outcrop communtiy. Oecologia. 1995;101:353-360.

11. Goldblum D, Rigg LS. Tree growth response to climate change at the deciduous boreal forest ecotone, Ontario, Canada. Canadian Journal of Forest Research. 2005;35:2709-2718.

12. Johnson SE, Abrams MD. Age class, longevity and growth rate relationships: Protracted growth increases in old trees in the eastern United States. Tree Physiology. 2009;29:1317-1328.

13. Aber JD, Nadelhoffer KJ, Steudler $P$, Melillo JM. Nitrogen saturation in northern forest ecosystems. BioScience. 1989;39: 378-286.

14. Aber J, McDowell W, Nadelhoffer K, Magill A, Berntson G, Kamakea M, McNulty S, Currie W, Rustand L, Fernandez I. Nitrogen saturation in temperate forest ecosystems. BioScience. 1998;48:921934.

15. Schwartz MD, Ahas R, Aasa A. Onset of spring starting earlier across the Northern emisphere. Global Change Biology. 2006;12:343-351.

16. McMahon SM, Parker GG, Miller DR. Evidence for a recent increase in forest 
growth. Proceedings of the National Academy of Sciences. 2010;107:36113615.

17. Abrams MD, Ruffner CM, Morgan TA. Tree-ring responses to drought across species and contrasting sites in the ridge and valley of central Pennsylvania. Forest Science. 1998;44:550-558.

18. Tebaldi C, Adams-Smich D, Heller N. The heat is on: U.S. temperature trends. Climate Central; 2012.

Available:http://www.climatecentral.org/wgt s/heat-is-on/HeatlsOnReport.pdf

19. Boer GJ, Flato G, Ramsden D. A transient climate change simulation with greenhouse gas and aerosol forcing: Projected climate to the twenty-first century. Climate Dynamics. 2000;16:427-450.

20. Gale J. Overview of $\mathrm{CO}_{2}$ emissions sources, potential, transport and geographical distribution of storage possibilities. In Proceedings of the workshop on $\mathrm{CO}_{2}$ dioxide capture and storage, Regina, Canada. 2002;15-29.

21. Montzka SA, Dlugokencky EJ, Butler JH. Non- $\mathrm{CO}_{2}$ greenhouse gases and climate change. Nature. 2011;476:43-50.

22. Friedlingstein $P$, Houghton RA, Marland G, Hackler J, Boden TA, Conway TJ, Canadell JG, Raupach MR, Ciais P, Le Quere C. Update on $\mathrm{CO} 2$ emissions. Nature Geoscience. 2010;3:811-812.

23. Mitchell JFB, Johns TC, Gregory JM, Tett SFB. Climate response to increasing levels of greenhouse gases and sulphate aerosols. Nature. 1995;376:501-504.

24. Dai A, Trenberth KE, Qian T. A global dataset of Palmer Drought Severitylndex for 1870-2002: Relationship with soil moisture and effects of surface warming. Journal of Hydrometeorology. 2004;5: 1117-1130.

25. Elsner JB, Jagger T, Niu XF. Changes in the rates of North Atlantic major hurricane activity during the $20^{\text {th }}$ century. Geophysical Research Letters. 2000;27: 1743-1746.

26. Klein JA, Harte J, Zhao XQ. Experimental warming causes large and rapid species loss, dampened by simulated grazing, on the Tibetan Plateau. Ecology Letters. 2004;7:1170-1179.

27. Beierkuhnlein $C$, Thiel $D$, Jentsch $A$, Willner E, Kreyling J. Ecotypes of European grass species respond differently to warming and extreme drought. Journal of Ecology. 2011;99:703713.

28. Fekedulegn D, Hicks Jr. RR, Colbert JJ. Influence of topographic aspect, precipitation and drought on radial growth of four major tree species in an Appalachian watershed. Forest Ecology and Management. 2003;177:409-425.

29. Petr M, Boerboom LGJ, van der Veen A, Ray D. A spatial and temporal drought risk assessment of three major tree species in Britain using probabilistic climate change projections. Climatic Change. 2014;124: 791-803.

30. Esper J, Cook ER, Schweingruber FH. Low-frequency signals in long tree-ring chronologies for reconstructing past temperature variability. Science. 2002;295: 2250-2253.

31. Black BA, Abrams MD. Disturbance history and climate response in an old-growth hemlock forest in Schall's Gap, central Pennsylvania. The Journal of the Torrey Botanical Society. 2005;132:103-114.

32. Salzer MW, Hughes MK, Bunn AG, Kipfmueller KF. Recent unprecedented tree-ring growth in bristlecone pine at the highest elevations and possible causes. Proceedings of the National Academy of Sciences. 2009;106:20348-20353.

33. Rubino DL, McCarthy BC. Dendroclimatological analysis of white oak (Quercus alba L., Fagaceae) from an oldgrowth forest of southeastern Ohio, USA. Journal of the Torrey Botanical Society. 2000;127:240-250.

34. Girardin MP, Guo XJ, De Jong R, Kinnard $C$, Bernier $P$, Raulier F. Unusual forest growth decline in boreal North America covaries with the retreat of Arctic sea ice. Global Change Biology. 2013;20:851-866.

35. Jacoby GC, D'Arrigo RD. Tree rings, carbon dioxide, and climatic change. Proceedings of the National Academy of Sciences. 1997;94:8350-8353.

36. D'Arrigo R. G. Jacoby, Pederson N, Frank D, Buckley B, Nachin B, Mijiddorj R, Dugarjav C. Mongolian tree-rings, temperature sensitivity and reconstructions of Northern Hemisphere temperatures. The Holocene. 2000;10:669-672.

37. Way DA, Oren R. Differential responses to changes in growth temperature between trees from different functional groups and 
biomes: A review and synthesis of data. Tree Physiology. 2010;30:669-688.

38. Mäkinen H, Nöjd P, Kahle HP, Neumann $\mathrm{U}$, Tveite B, Mielikäinen K, Röhle $\mathrm{H}$, Spiecker H. Radial growth variation of Norway spruce (Picea abies (L.) Karst.) across latitudinal and altitudinal gradients in central and northern Europe. Forest Ecology and Management. 2002;171:243259.

39. Jump AS, Hunt JM, Penuelas J. Rapid climate change-related growth decline at the southern range edge of Fagus sylvatica. Global Change Biology. 2006;12: 2163-2174.

40. Tainter FH, Retzlaff WA, Starkey DA, Oak SW. Decline of radial growth in red oaks is associated with short-term changes in climate. European Journal of Forest Pathology. 1990;20:95-105.

41. Voelker SL, Muzika RM, Guyette RP. Individual tree and stand level influences on the growth, vigor, and decline of red oaks in the Ozarks. Forest Science. 2008;54:8-20.

42. Oberhuber W, Kofler W. Topographic influences on radial growth of Scots pine (Pinus sylvestris L.) at small spatial scales. Plant Ecology. 2000;146:229-238.

43. Ackerly D, Knight C, Weiss S, Barton K, Starmer K. Leaf size, specific leaf area and microhabitat distribution of chaparral woody plants: Contrasting patterns in species level and community level analyses. Oecologia. 2002;130:449-457.

44. Anning AK, Rubino DL, Sutherland EK, McCarthy BC. Dendrochronological analysis of white oak growth patterns across a topographic moisture gradient in southern Ohio. Dendrochronologia. 2013; 31:120-128.

45. Kulman HM. Effects of insect defoliation on growth and mortality of trees. Annual Review of Entomology. 1971;16:289-324.

46. Davidson CB, Gottschalk KW, Johnson JE. Tree mortality following defoliation by the European gypsy moth (Lymantria dispar L.) in the United States: A review. Forest Science. 1999;45:74-84.

47. Jedlicka J, Vandermeer J, Aviles-Vazquez K, Barros O, Perfecto I. Gypsy moth defoliation of oak trees and a positive response of red maple and black cherry: an example of indirect interaction. The
American Midland Naturalist. 2004;152: 231-236.

48. Sholes ODV. Effects of ice storm damage on radial growth of Quercus spp. The Journal of the Torrey Botanical Society. 2013;140:364-368.

49. Foster DR. Species and stand response to catastrophic wind in central New England, USA. The Journal of Ecology. 1988b;76: 135-151.

50. Merrens EJ, Peart DR. Effects of hurricane damage on individual growth and stand structure in a hardwood forest in New Hampshire, USA. Journal of Ecology. 1992;80:787-795.

51. Yamaguchi DK. A simple method for cross-dating increment cores from living trees. Canadian Journal of Forest Research. 1991;21:414-416.

52. Grissino-Mayer HD. Evaluating crossdating accuracy: A manual and tutorial for the computer program COFECHA; 2001.

53. Cook ER, Holmes RL. Users manual for program ARSTAN. Laboratory of TreeRing Research, University of Arizona, Tucson, USA; 1986.

54. Pan C, Tajchman SJ, Kochenderfer JN. Dendroclimatological analysis of major forest species of the central Appalachians. Forest Ecology and Management. 1997;98:77-87.

55. Biondi F, Waikul K. DENDROCLIM2002: A $\mathrm{C}++$ program for statistical calibration of climate signals in tree-ring chronologies. Computers \& Geosciences. 2004;30:303311.

56. Nowacki GJ, Abrams MD. Community and edaphic analysis of mixed oak forests in the ridge and valley province of central Pennsylvania. Eighth Central Hardwood Forest Conference (L. McCormick and K. Gottschalk, ed.). 1991;247-260.

57. Orwig DA, Abrams MD. Impacts of early selective logging on the dendroecology of an old-growth, bottomland hemlock-white pine-northern hardwood forest on the Allegheny Plateau. Journal of the Torrey Botanical Society. 1999;126:234-244.

58. Abrams MD. Native Americans, Smoky Bear and the rise and fall of eastern oak forests. Penn State Environmental Law Review. 2010;19:141-154.

59. Liebhold A, Elkinton J, Williams D, Muzika RM. What causes outbreaks of the gypsy 
moth in North America? Population Ecology. 2000;42:257-266.

60. United States Geological Survey (USGS). Mineral resource on-line spatial data; 2013.

Available:http://mrdata.usgs.gov/sgmc/pa.h $\underline{\mathrm{tml}}$

61. Braker WL. Soil survey of centre county, Pennsylvania. U.S.D.A. Soil Conservation Service, Washington, D.C.; 1981.

62. Burns RM, Honkala BH. Silvics of North America. Vol. 1. Conifers. US Dep. Agric. Agric. Handb. 1990;654.

63. Tardif JC, Conciatori F, Nantel P, Gagnon D. Radial growth and climate responses of white oak (Quercus alba) and northern red oak (Quercus rubra) at the northern distribution limit of white oak in Quebec, Canada. Journal of Biogeography. 2006;33:1657-1669.

64. Kubiske ME, Abrams MD. Photosynthesis, water relations and leaf morphology of xeric versus mesic Quercus rubra ecotypes in central Pennsylvania in relation to moisture stress. Canadian Journal of Forest Research. 1992;22:14021407.

65. Orwig DA, Abrams MD. Variation in radial growth responses to drought among species, site and canopy strata. Trees. 1997;11:474-484.

66. Eilmann B, Rigling A. Tree-growth analyses to estimate tree species' drought tolerance. Tree physiology. 2012;32:178187.

67. Kubiske ME, Abrams MD. Stomatal and nonstomatal limitations of photosynthesis in 19 temperate tree species on contrasting sites during wet and dry years. Plant, Cell \& Environment. 1993;16:11231129.

68. Carpenter SB, Smith ND. A comparative study of leaf thickness among southern Appalachian hardwoods. Canadian Journal of Botany. 1981;59:1393-1396.

69. Abrams MD. Adaptations and responses to drought in Quercus species of North America. Tree Physiology. 1990;7:227238.

70. Kleiner KW, Abrams MD, Schultz JC. The impact of water and nutrient deficiencies on the growth, gas exchange and water relations of red oak and chestnut oak. Tree Physiology. 1992;11:271-287.
71. Struve DK, Sternberg $P$, Drunasky $N$, Bresko K, Gonzalez R. Growth and water use characteristics of six eastern North American oak (Quercus) species and the implications for urban forestry. Arboriculture \& Urban Forestry. 2006;32: 202-213.

72. Espeleta JF, Donovan LA. Fine root demography and morphology in response to soil resources availability among xeric and mesic sandhill tree species. Functional Ecology. 2002;16: 113-121.

73. Johnson SE. Comparison of growth rates between age classes for a variety of trees in the Eastern U. S. Master's thesis, The Pennsylvania State University, University Park; 2007.

74. Yoder BJ, Ryan MG, Waring RH, Schoettle AW, Kaufmann MR. Evidence of reduced photosynthetic rates in old trees. Forest Science. 1994;40:513-527.

75. Weiner J, Thomas SC. The nature of tree growth and the "age-related decline in forest productivity." Oikos. 2001;94:374376.

76. Day ME, Greenwood MS, White AS. Agerelated changes in foliar morphology and physiology in red spruce and their influence on declining photosynthetic rates and productivity with tree age. Tree Physiology. 2001;21:1195-1204.

77. Mencuccini M, Martinez-Vilalta J, vanderklein D, Hamid HA, Korakaki E, Lee S, Michiels B. Size-mediated ageing reduces vigour in trees. Ecology Letters. 2005;8:1183-1190.

78. Mencuccini M, Martínez-Vilalta J, Hamid HA, Korakaki E, Vanderklein D. Evidence for age-and size-mediated controls of tree growth from grafting studies. Tree Physiology. 2007;27:463-473.

79. Niinemets Ü. Stomatal conductance alone does not explain the decline in foliar photosynthetic rates with increasing tree age and size in Picea abies and Pinus sylvestris. Tree Physiology. 2002;22:515535.

80. Coomes DA, Allen RB. Effects of size, competition and altitude on tree growth. Journal of Ecology. 2007;95:1084-1097.

81. Smith FW, Long JN. Age-related decline in forest growth: An emergent property. Forest Ecology and Management. 2001;144:175-181. 
82. Binkley D, Stape JL, Ryan MG, Barnard $\mathrm{HR}$, Fownes J. Age-related decline in forest ecosystem growth: And individual tree, stand-structure hypothesis. Ecosystems. 2002;5:58-67.

83. Foster JR, D'Amato AW, Bradford JB. Looking for age-related growth decline in natural forests: Unexpected biomass patterns from tree rings and simulated mortality. Oecologia. 2014;174:363-374.

84. Western AW, Bloschl G, Willgoose GR, McMahon TA, Grayson RB. Field investigations of spatial organisation of soil moisture in a small catchment. In Hydrology and Water Resources Symposium 1996: Water and the Environment; Preprints of Papers (p. 547). Institution of Engineers, Australia; 1996.

85. Boerner RE, Morris SJ, Sutherland EK, Hutchinson TF. Spatial variability in soil nitrogen dynamics after prescribed burning in Ohio mixed-oak forests. Landscape Ecology. 2000;15:425-439.

86. Boerner REJ, Brinkman JA. Fire frequency and soil enzyme activity in southern Ohio oak-hickory forests. Applied Soil Ecology. 2003;23:137-146.

87. Knorr MA, Boerner REJ, Rillig MC. Glomalin content of forest soils in relation to fire frequency and landscape position. Mycorrhiza. 2003;13:205-210.

88. Wu R, Grissom JE, McKeand SE, O'Malley DM. Phenotypic plasticity of fine root growth increases plant productivity in pine seedlings. BMC Ecology. 2004;4:1-6.

89. Hanna AY, Harlan PW, Lewis DT. Soil available water as influenced by landscape position and aspect. Agronomy Journal. 1982;74:999-1004.

90. Addington RN, Donovan LA, Mitchell RJ, Vose JM, Pecot SD, Jack SB, Hacke UG, Sperry JS, Oren R. Adjustments in hydraulic architecture of Pinus palustris maintain similar stomatal conductance in xeric and mesic habitats. Plant, Cell and Environment. 2006;29:535-545.

91. Lorimer CG. Age structure and disturbance history of a southern Appalachian virgin forest. Ecology. 1980;61:1169-1184.

92. Thornton PE, Law BE, Gholz HL, Clark KL, Falge E, Ellsworth DS, Goldstein $A H$, Monson RK, Hollinger D, Falk M, Chen J, Sparks JP. Modeling and measuring the effects of disturbance history and climate on carbon and water budgets in evergreen needle leaf forests. Agricultural and Forest Meteorology. 2002;113:185-222.

93. Foster DR, Boose ER. Patterns of forest damage resulting from catastrophic wind in central New England, USA. Journal of Ecology. 1992;80:79-98.

94. Abrams MD, Orwig DA, DeMeo TE. Dendroecological analysis of successional dynamics for a presettlement origin white pine-mixed oak forest in the southern Appalachians, U.S.A. Journal of Ecology. 1995;83:123-133.

95. Gelber B. The Pennsylvania weather book. Rutgers University Press; 2002.

96. Robertson PA. Factors affecting tree growth on three lowland sites in Southern Illinois. American Midland Naturalist. 1992;128:218-236.

97. Luken JO, Porter D, Agard B. Relationships between recent growth and climate for rural and urban Fraxinus americana. L. Trans. Ky. Acad. Sci. 1994;55:102-107.

98. Pederson N, Cook ER, Jacoby GC, Peteet $\mathrm{DM}, \mathrm{Griffin} \mathrm{KL}$. The influence of winter temperatures on the annual radial growth of six northern range margin tree species. Dendrochronologia. 2004;22:7-29.

99. Huang J, Tardif JC, Bergeron Y, Denneler $B$, Berninger F, Girardin MP. Radial growth response of four dominant boreal tree species to climate along a latitudinal gradient in the eastern Canadian boreal forest. Global Change Biology. 2010;16: 711-731.

100. Augspurger CK. Spring 2007 warmth and frost: Phenology, damage andrefoliation in a temperate deciduous forest. Functional Ecology. 2009;23:1031-1039.

101. Hufkens $\mathrm{K}$, Friedl MA, Keenan TF, Sonnentag $\mathrm{O}$, Bailey A, O'Keefe J, Richardson AD. Ecological impacts of a widespread frost event following early spring leaf-out. Global Change Biology. 2012;18:2365-2377.

102. Hudson-Dunn A, de Beurs KM. Land surface phenology of North American mountain environments using moderate resolution imaging spectroradiometer data. Remote Sensing of Environment. 2011;115:1220-1233.

103. Fritts HC. Tree rings and climate. Academic Press, New York; 1976.

104. Koslowski TT, Kramer PJ, Pallardy SG. The physiological ecology of woody plants. Academic Press, New York; 1991. 
105. D'Arrigo RD, Schuster WS, Lawrence DM, Cook ER, Wiljanen M, Thetford RD. Climate-growth relationships of eastern hemlock and chestnut oak from Black Rock Forest in the highlands of southeastern New York. Tree-Ring Research. 2001;57:183-190.

106. Saurer M, Borella S, Schweingruber F, Siegwolf R. Stable carbon isotopes in tree rings of beech: Climatic versus site-related influences. Trees. 1997;11:291-297.

107. Villalba R, Veblen TT, Ogden J. Climatic influences on the growth of subalpine trees in the Colorado Front Range. Ecology. 1994;75:1450-1462.

108. Peterson DW, Peterson DL. Effects of climate on radial growth of subalpine conifers in the North Cascade Mountains. Canadian Journal of Forest Research. 1994;24:1921-1932.

109. Gea-Izquierdo G, Martín-Benito D, Cherubini $P$, Isabel C. Climate-growth variability in Quercus ilex L. west Iberian open woodlands of different stand density. Annals of Forest Science. 2009;66:802.

110. Ordoñez JC, Van Bodegom PM, Witte JPM, Wright IJ, Reich PB, Aerts R. A global study of relationships between leaf traits, climate and soil measures of nutrient fertility. Global Ecology and Biogeography. 2009;18:137-149.

111. Rennenberg H, Dannenmann M, Gessler A, Kreuzwieser J, Simon J, Papen $H$. Nitrogen balance in forest soils: nutritional limitation of plants under climate change stresses. Plant Biology. 2009;11:4-23.

112. Rozas V. Detecting the impact of climate and disturbances on tree-rings of Fagus sylvatica L. and Quercus robur L. in a lowland forest in Cantabria, Northern Spain. Annals of Forest Science. 2001;58: 237-251.

113. Bond-Lamberty B, Rocha AV, Calvin K, Holmes B, Wang C, Goulden ML. Disturbance legacies and climate jointly drive tree growth and mortality in an intensively studied boreal forest. Global Change Biology. 2014;20:216-227.

114. Foster DR. Disturbance history, community organization and vegetation dynamics of the old-growth Pisgah Forest, southwestern New Hampshire, USA. The Journal of Ecology. 1988a;76:105-134.

115. National Oceanic and Atmospheric Administration (NOAA). Storm Data 8:5 Washington; 1966.

(c) 2017 Bouma and Abrams; This is an Open Access article distributed under the terms of the Creative Commons Attribution License (http://creativecommons.org/licenses/by/4.0), which permits unrestricted use, distribution, and reproduction in any medium, provided the original work is properly cited. 